\title{
Approaches to Create Concepts of Sustainable Tourism and Hospitality Development in the Regions
}

\author{
Ismailov Adhambek Bakhramovich \\ Department of Tourism, Tourism and Economics Faculty, Urgench State University, Urgench City, Uzbekistan
}

Email address:

goodluck_0714@mail.ru

\section{To cite this article:}

Ismailov Adhambek Bakhramovich. Approaches to Create Concepts of Sustainable Tourism and Hospitality Development in the Regions. International Journal of Management and Fuzzy Systems. Vol. 4, No. 2, 2018, pp. 19-23. doi: 10.11648/j.ijmfs.20180402.12

Received: June 30, 2018; Accepted: July 9, 2018; Published: August 9, 2018

\begin{abstract}
Despite the rich tourist and recreational resource base and a wide network of tourism enterprises, Uzbekistan still lacks a clear strategy for tourism development that meets global and world standards. According to the tourist arrival, it occupies one of the last places in the World. Therefore, the discussion of the strategy of truly sustainable development of tourism in the country should be the starting point for taking measures to implement it. The article highlights the different approaches and methods for the determination of indicators of sustainable development of tourism. In particular, it deals with the idea of risk management in tourist destinations and their economic effect, which reveal the importance of risk management in the definition of sustainable development as well as creating a method of differential grouped socio-economic indicators required for the functioning of the system.
\end{abstract}

Keywords: Tourism, Sustainable Development, Structure, Ranking, Sustainability, Risk Management

\section{Introduction}

Scientific and technical and socio-economic progress has led to accelerated development of tourism. Because of this, in places visited by tourists, serious problems appeared in the field of ecology, culture and social development. The uncontrolled growth of tourism, driven by the desire to quickly make a profit, often leads to negative consequences damage to the environment and local communities. Sustainable tourism should also maintain a high level of satisfaction of tourists' needs, using the multifaceted requests of tourists, increasing their awareness (awareness) of sustainability of results and promoting practical activities for sustainable tourism among them. From a methodological point of view, the terms "criterion" and "indicator" should be considered close in meaning as indicators of the trend (dynamics) of any process. An indicator can be considered a more general indicator that reflects this trend (dynamics) of a process. Criterion is an estimated indicator showing the degree (significance, speed) of a given trend (dynamics) of a process, expressed as a rule in quantitative form (in units of measure, relative fractions or percentages). Therefore, from the methodological point of view, the term "criterion" takes a subordinate position in comparison with the "indicator" as a more specific (and not a general) quantitative indicator of this trend. It is also necessary to determine what should be considered "sustainable development" (in this case tourism, resorts and recreation), and how sustainable development differs from simple (unstable). The main indicator (indicator) of sustainable development is that, unlike the unstable one, it is controlled (by management bodies, the public) and predicted.

\section{Method}

Sustainable development of tourism, Tourism sustainable development and role of tourism in the regional sustainable development of the economy have widely being learned by scholars and research of the world. Ottenbacher, M. created new way as a case study "Sustainability criteria for tourism attractions: a case study of Germany." [1], Ngo, Tramy, Gui Lohmann, and Rob Hales with their work "Collaborative marketing for the sustainable development of communitybased tourism enterprises: voices from the field" [2] have opned the real factors of marketing tools for sustainable tourism development and the role of marketing strategies for the local tourism enterprises. Besides, Boluk, Karla, Christina T. Cavaliere, and Freya Higgins-Desbiolles [3], 
Carley, Michael, and Ian Christie [4], Peng, Kua-Hsin, and Gwo-Hshiung Tzeng [5], Kazak, A. N. [6], Lyon, Andrew, Philippa Hunter-Jones, and Gary Warnaby [7], Liu, Jingjing [8], Alvarado-Herrera, Alejandro [9] also learned and created different types of indicators systems and theories to evaluate tourism sustainable development and the regional sustainable development.

During the years of independence, the economy of the Republic of Uzbekistan has been evolving on basis of the national model developed by the first President Islam Karimov. This model based on well-known five principles priority of economy over politics, role of state as the main reformer, rule-of-law, conducting strong social policy, stageby-stage transition to market economy as a strategy of construction of legal, democratic state, based on market economy. As a continuous of this strategic plans President of Uzbekistan Shavkat Mirziyoyev signed a decree "On Uzbekistan's Development Strategy " The document is aimed at improving the efficiency of the reforms, creating conditions for full and accelerated development of the state and society, implementing the priority areas for modernization and liberalization of the country in all spheres of the life. The strategy includes five priority directions improving state and public construction, ensuring rule of law and reforming judicial-legal system, developing and liberalizing economy, developing social sphere and ensuring security, inter-ethnic harmony and religious tolerance, implementing balanced, mutually beneficial and constructive foreign policy [10]. As a result of reforms and such kind of models, the structure of the economy was radically changed, a reliable legal framework for dynamic economic development and favorable investment climate were created.

As we can see today, the model is working well. Achievements and prospects of economic development of the country, highly recognized by authoritative international financial and economic organizations.

Tourism also is one of the main sphere in these kinds of state program. Nowadays there are many programs, state projects and decrees of the president has been adopted. All of them are for the purpose of creation of favorable economic

\begin{tabular}{|c|c|c|}
\hline \multicolumn{2}{|c|}{$\begin{array}{l}\text { TRAVEL \& TOURISM'S DIRECT } \\
\text { CONTRIBUTION TO GDP }\end{array}$} & $\begin{array}{c}2016 \\
\text { (USSbn) }\end{array}$ \\
\hline \multirow[t]{2}{*}{14} & Turkey & 29.1 \\
\hline & World Average & 19.1 \\
\hline 23 & Russian Federation & 15.8 \\
\hline 34 & Iran & 11.9 \\
\hline$\pi$ & Kazakhstan & 2.4 \\
\hline 88 & Azerbaijan & 1.4 \\
\hline 93 & Ukraine & 1.4 \\
\hline \multirow[t]{2}{*}{99} & Georgia & 1.2 \\
\hline & Central Asia Average & 0.9 \\
\hline 122 & Uzbekistan & 0.7 \\
\hline 135 & Armenia & 0.4 \\
\hline 168 & Kyrgyzstan & 0.1 \\
\hline
\end{tabular}

and organization-legal conditions for intensive tourism development as strategic industry of national economy, most complete and effective use of huge tourist capacity of regions, cardinal enhancement of management of tourist industry, creation and promotion on the world markets of national tourist product, forming of positive image of Uzbekistan in the sphere of tourism. One of them is "On additional organizational measures to create favorable conditions for the development of the tourism potential of the Republic of Uzbekistan"[11]. According to the decree, from 10 February 2018, citizens of Israel, Indonesia, the Republic of Korea, Malaysia, Singapore, Turkey and Japan can visit Uzbekistan without visas for the period of 30 days. The document underlined that members of the crews of aircrafts of foreign airlines, carrying out regular flights to Uzbekistan, also received the right to visit the country without obtaining visas.

\section{Result and Discussion}

According to the information of the the State Tourism Committee the number of tourists visiting the country in 2017 exceeded 2 million 520 thousand and increased by $24.3 \%$ compared to 2016 , while export of tourist services increased by $24 \%$ compared to 2016 to 1 billion 557 million dollars. In addition, 101 placement facilities were created in 2017, with a total number of 1,355 places, and 128 legal entities providing tour operator services are registered, the current number of accommodation facilities is 851, and the number of tour operators is 561. As part of the implementation of a set of measures to ensure the safety of life and health of tourists, 442 organizations providing tourist services are certified, of which 221 provide hotel and 221 tour operator services. During the period under review, issuing licenses for the right to carry out tour operator activities for 128 entrepreneurs was organized. Year by year tourism in Uzbekistan is developing and its place in various indicators increasing. The table below shows us the main indicators in the sphere of the tourism in Uzbekistan compering with other most related countries.

\begin{tabular}{|c|c|c|}
\hline $\begin{array}{l}\text { TRAVEL \& TOURISM'S TOTAL } \\
\text { CONTRIBUTION TO GDP }\end{array}$ & $\begin{array}{c}2016 \\
\text { (USSbn) }\end{array}$ \\
\hline 14 & Turkey & 88.0 \\
\hline 18 & Russian Federation & 62.6 \\
\hline & World Average & 57.3 \\
\hline 33 & Iran & 31.5 \\
\hline 68 & Kazakhstan & 7.9 \\
\hline 83 & Azerbaijan & 5.1 \\
\hline 85 & Ukraine & 5.0 \\
\hline 92 & Georgia & 3.9 \\
\hline & Central Asia Average & 3.6 \\
\hline 117 & Uzbekistan & 2.1 \\
\hline 127 & Armenia & 1.5 \\
\hline 166 & Kyrgyzstan & 0.3 \\
\hline
\end{tabular}




\begin{tabular}{|r|c|c|}
\hline \multicolumn{2}{|c|}{ TRAVEL \& TOURISM INVESTMENT } & $\begin{array}{c}2016 \\
\text { (US\$bn) }\end{array}$ \\
\hline 10 & Turkey & 17.5 \\
\hline 24 & Russian Federation & 5.9 \\
\hline & World Average & 4.4 \\
\hline 39 & Iran & 3.5 \\
\hline 57 & Kazakhstan & 1.7 \\
\hline 100 & Central Asia Average & 0.7 \\
\hline 105 & Azerbaijan & 0.3 \\
\hline 118 & Ukraine & 0.3 \\
\hline 131 & Georgia & 0.2 \\
\hline 148 & Armenia & 0.2 \\
\hline 154 & Kyrgyzstan & 0.1 \\
\hline
\end{tabular}

\begin{tabular}{|c|l|c|}
\hline VISITOR EXPORTS & $\begin{array}{c}2016 \\
\text { (US\$bn) }\end{array}$ \\
\hline 13 & Turkey & 26.5 \\
\hline 32 & Russian Federation & 11.4 \\
\hline & World Average & 7.6 \\
\hline 57 & Iran & 4.2 \\
\hline 65 & Azerbaijan & 2.9 \\
\hline 74 & Georgia & 2.3 \\
\hline 85 & Kazakhstan & 1.7 \\
\hline 93 & Ukraine & 1.5 \\
\hline & Central Asia Average & 1.1 \\
\hline 110 & Armenia & 0.9 \\
\hline 132 & Kyrgyzstan & 0.4 \\
\hline 149 & Uzbekistan & 0.2 \\
\hline
\end{tabular}

Figure 1. Country rankings: absolute contribution, 2016 [12].

The competing destinations selected are those that offer a similar tourism product and compete for tourists from the same set of origin markets. These tend to be, but are not exclusively, geographical neighbors. The tables on pages 710 provide brief extracts from the full WTTC Country League Table Rankings, highlighting comparisons with competing destinations as well as with the world and regional average. Averages in above tables are simple cross-country averages [12].

In accordance with the report of the World Economic Forum, Uzbekistan has the second-fastest-growing economy, with projected growth of $7.6 \%$ thanks to rising oil prices, benign global financing conditions, robust growth in the Euro Area, and generally supportive policies among governments of several large countries in the region [13]. The important role in achieving such results is played by structural, strategic programs and goal attracting foreign investments. In its turn, the rich experience on attraction of foreign investments at the expense of shaping favorable business environment, modernization and renewal of production, accelerated development of small business and private enterprises ensured achievement of high results. Especially in tourism sphere of economy. Attracting foreign investments to tourism sphere is one of the most important matter in developing countries like Uzbekistan. To attract investments in the development of tourism infrastructure, taking into account the specifics of the industry is necessary to give effect to the organizational and economic structure to stimulate investment activity in the objects of the tourism industry. Active involvement in the investment management practice could make a significant contribution to the development of infrastructure of the tourism industry of Uzbekistan regions. Firstly, must gain ability of ranking sustainably of the touristic destination. To monitor the process of sustainable development and to improve the planning process there is a need to have indicators that help to evaluate and co-ordinate sustainable development. In this way the tourism industry, like any other component of the economy, is subject to specific risks, which can affect, on a long or short term, the companies' profitability and sometimes even their survival in this field. The basic premise of risk analysis in any economic system is its identification with the quantitative value or measure of danger. If it is properly utilize risk management model in tourism, it will be base for sustainable development model of tourism. The model (Figure 1) is an adaptation of the International Organization for Standardization's (ISO) risk management model, which can be used in touristic sector of economics.

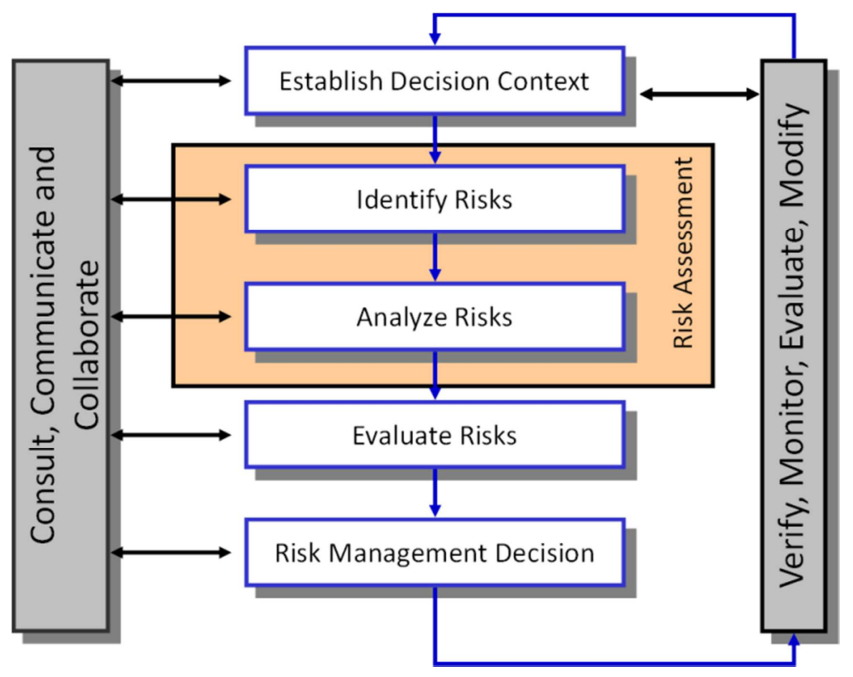

Figure 2. ISO 31000-General model of risk management [14].

The experience of the largest world tour operators showed that the right strategy and competent assessment of business risks allows the company to identify target markets, to select the permanent reliable partners, to significantly increase the sales volume, market share. Considering the issues of risk management in the tourism and the tourist industry, should be divided business risks that can be minimized through the implementation of effective management of the enterprise.

Ranking the risks is initial step of managing sustainable development in economy. Sustainable tourism development 
requires the competent participation of all stakeholders relevant to this case. Achieving sustainable tourism is a continuous process that requires constant monitoring of impacts on the social-economic environment, by introducing corrective measures. According to world, standards of WTO (World tourism organization) indicators should be identified for all three aspects of sustainable tourism development - economic, social and ecological.

As considering these factors, it is necessary to create Uzbek model of complex indicating system of sustainable development of tourism sector (figure 2). The current model's working process consists of these main steps. (figure 2) Which is shown below: preparation of input data, data handling, measures and check their effectiveness.

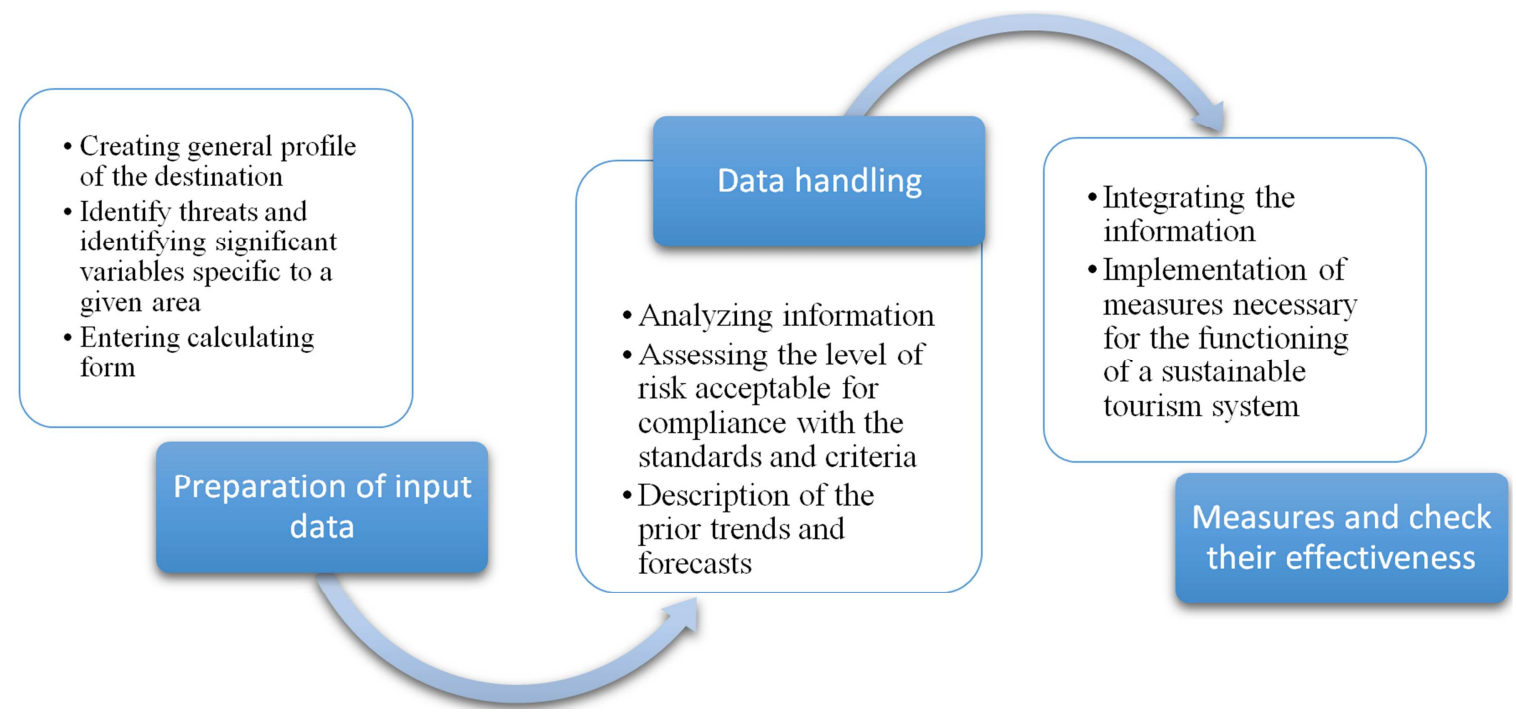

Figure 3. Working procces of the model "Sustainable development indicators of tourism.

Table 1. Approaches to create sustainable development indicators of tourism.

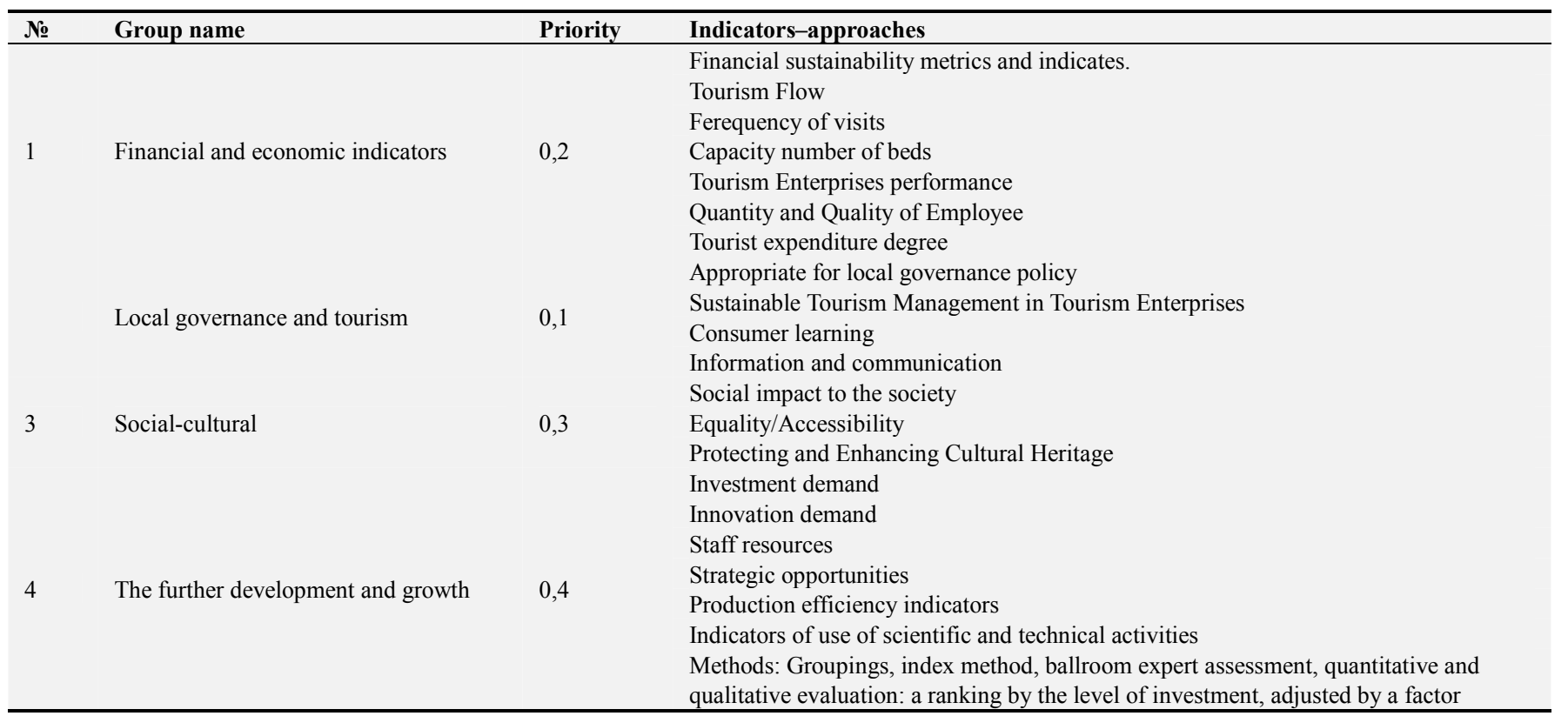

\section{Conclusion}

In general, the proposals set out here for the development of a methodological basis and a system of indicators and criteria for the sustainable development of tourism, resorts and recreation represent the author's point of view on this problem and, naturally, do not pretend to the truth in the last instance. They can also be supplemented by special economic, sociological and environmental arguments. The author expresses confidence that his views and proposals will contribute to the solution of such an important problem as the truly sustainable development of tourism in Uzbekistan.

The development of tourism - is a kind of art, you need to find a clear, thought-out concept of how correctly fit into the unique natural landscape, at the same time take into account the interests of local residents and tourists, the state and business. The key is to change the approach to pricing, 
taxation, the pace of tourism development and volume of tourist flows, which, combined with a holistic approach and long-term planning can be effective ways for the implementation of sustainable tourism development strategy. Focusing on the needs of destination, experience exchange, availability of information and preventive actions management can serve as a basis for sustainable development of tourism in Uzbeksitan.

\section{References}

[1] Ottenbacher, Michael C., et al. "Sustainability criteria for tourism attractions: a case study of Germany." Sustainable Development: Concepts, Methodologies, Tools, and Applications. IGI Global, 2018. 1526-1548.

[2] Ngo, Tramy, Gui Lohmann, and Rob Hales. "Collaborative marketing for the sustainable development of communitybased tourism enterprises: voices from the field." Journal of Sustainable Tourism (2018): 1-19.

[3] Boluk, Karla, Christina T. Cavaliere, and Freya HigginsDesbiolles. "Critical thinking to realize sustainability in tourism systems: reflecting on the 2030 sustainable development goals: Guest Editors." (2017): 1201-1204.

[4] Carley, Michael, and Ian Christie. Managing sustainable development. Routledge, 2017.

[5] Peng, Kua-Hsin, and Gwo-Hshiung Tzeng. "Exploring heritage tourism performance improvement for making sustainable development strategies using the hybrid-modified MADM model." Current Issues in Tourism (2017): 1-27.

[6] Kazak, A. N. "Qualitative analysis of the mathematical model of tourism development, proposed by Casagrandi and
Rinaldi." Soft Computing and Measurements (SCM), 2017 XX IEEE International Conference on. IEEE, 2017.

[7] Lyon, Andrew, Philippa Hunter-Jones, and Gary Warnaby. "Are we any closer to sustainable development? Listening to active stakeholder discourses of tourism development in the Waterberg Biosphere Reserve, South Africa." Tourism Management 61 (2017): 234-247.

[8] Liu, Jingjing, et al. "Urban livability and tourism development in China: Analysis of sustainable development by means of spatial panel data." Habitat International 68 (2017): 99-107.

[9] Alvarado-Herrera, Alejandro, et al. "A scale for measuring consumer perceptions of corporate social responsibility following the sustainable development paradigm." Journal of Business Ethics 140. 2 (2017): 243-262.

[10] "Collection of Legislation of the Republic of Uzbekistan ", February 13, 2017, No. 6, article 70 Decree of the President of the Republic of Uzbekistan" On the strategy for further development of the Republic of Uzbekistan "07. 02. $2017 \mathrm{~N}$ UP-4947.

[11] National Legislation Database (www.lex.uz), 6 February 2018, N УП-5326 Decree of the President of the Republic of Uzbekistan "On additional organizational measures to create favorable conditions for the development of the tourism potential of the Republic of Uzbekistan".

[12] World Travel and Tourism Council: Economic Impact 2017 March 2017, "ECONOMIC IMPACT 2017 UZBEKISTAN" p. 4-6.

[13] https://www.weforum.org/agenda/2017/06/these-are-theworld-s-fastest-growing-economies-in-2017-2/ 2018 World Economic Forum

[14] International Organization for Standardization. ISO 31000 Risk management. Retrieved November 15, 2012. 